\title{
Why do people consent to receiving SARS-CoV2 vaccinations? A Representative Survey in Germany
}

\section{Harald Walach ( $\nabla$ hwalac@gmail.com )}

Change Health Science Institute https://orcid.org/0000-0003-4603-7717

\section{Michael Ofner}

Medyco International https://orcid.org/0000-0003-0964-0955

\section{Viviane Ruof}

Change Health Science Institute

\section{Markus Herbig \\ Debaro $\mathrm{GmbH}$}

\section{Rainer J. Klement}

Leopoldina Hospital https://orcid.org/0000-0003-1401-4270

\section{Research Article}

Keywords: Covid-19, SARS-CoV2, vaccination, vaccination hesitancy, survey, representative

Posted Date: January 3rd, 2022

DOI: https://doi.org/10.21203/rs.3.rs-1216502/v1

License: (c) (i) This work is licensed under a Creative Commons Attribution 4.0 International License. Read Full License 


\title{
Why do people consent to receiving SARS-CoV2 vaccinations?
}

\author{
A Representative Survey in Germany
}

\section{Harald Walach $(1,2,3)$, Michael Ofner $(4,5)$, Viviane Ruof (2), Markus Herbig (6), Rainer J. Klement (7)}

\footnotetext{
1 Universität Witten-Herdecke, Dept. Psychology, Witten, Germany

2 CHS Institut, Berlin, ORCID ID: 0000-0003-4603-7717

3 Next Society Institute, Kazimieras Simonavicius University, Vilnius, Lithuania

$4 \quad$ Medyco International, Dubai

5 Medical University of Graz, Dept. Immunology and Pathophysiology, Graz, Austria, ORCID ID: 0000-0003-0964-0955

6 Debaro GmbH, Munich, Germany

7 Department of Radiation Oncology, Leopoldina Hospital Schweinfurt, Schweinfurt, Germany ORCID ID: 0000-0003-1401-4270
}

Correspondence:

Prof. Harald Walach

CHS-Institut

Schönwalder Str. 17

D - 13347 Berlin

hwalac@gmail.com

+493046797436

Word Count: Abstract 283

Text: 3.648

References: 65

Tables: 7

Figures: 1 


\begin{abstract}
Objective: to answer the question: Why do people consent to being vaccinated with novel vaccines against SARS-CoV2?
\end{abstract}

Design: Representative survey

Setting: Online panel

Participants: 1032 respondents of the general German population

Method: a representative survey among German citizens in November/December 2021 which resulted in 1032 complete responses on vaccination status, socio-demographic parameters and opinions about the COVID-19 situation.

Results: Almost $83 \%$ of the respondents were vaccinated. The major motivation was fear of medical consequences of an infection and the wish to lead a normal life again. The major motivation to be not vaccinated was the fear of side effects and skepticism about long-term effectiveness and safety. Sixteen percent of vaccinated respondents reported some serious side effect, while more than 30\% reported health improvements, mostly due to the relief of psychological stress and social reintegration. We also validated a "Corona Orthodoxy Score COS" consisting of 7 items reflecting opinions on Covid-19. The scale is reliable (alpha $=0.76$ ) and unidimensional. The COS was a highly significant predictor of vaccination status and readiness to be vaccinated in a multivariable logistic regression model. Those who were vaccinated were more likely to live in smaller households $(\mathrm{OR}=0.82, \mathrm{p}=0.024)$, had a higher income $(\mathrm{OR}=1.27, \mathrm{p}<0.001)$, a higher $\mathrm{COS}$ score $(\mathrm{OR} 1.4, \mathrm{p}<0.0001)$ and utilized less alternative media $(\mathrm{OR}=0.44, \mathrm{p}=0.0024)$ and scientific publications $(\mathrm{OR}=0.42, \mathrm{p}=0.011)$ as information sources.

Conclusions: The major motives for being vaccinated are fear of medical symptoms and the wish to lead a normal life. Those not wanting to be vaccinated cite a lack of knowledge regarding long-term safety and side effects as reasons. This can likely only be overcome by careful and active long-term efficacy and safety monitoring.

Key Words: Covid-19, SARS-CoV2, vaccination, vaccination hesitancy, survey, representative

Data Availability Statement:

Data will be made available after publication on the Open Science Framework platform. 


\section{Strengths and Limitations of the Study}

This is the first representative survey in a German population asking about reasons for or against Covid-19 vaccinations

We present survey data on the three most important reasons why people want to be vaccinated or not

We constructed a Corona Orthodoxy Score (COS), a scale that measures adherence to the mainstream narrative about the corona virus pandemic, which is reliable and unidimensional

We conducted logistic regression analyses to predict whether someone is willing to be vaccinated or vaccinated

A limitation is the fact that complete representativity is difficult to achieve with online panels. 


\section{Introduction}

In Germany and elsewhere public discourse about how to deal with the SARS-CoV2 pandemic is dominated by the opinion that it is important to achieve a high number of Covid-19 vaccinations in the population. Politicians and media present these novel vaccinations as beneficial and assenting to receiving them as an act of solidarity and respect for others. In parallel, politicians and other stakeholders talk in public about restricting access to public participation for those that are not vaccinated. This increases implicit pressure on persons that have hitherto refused to be vaccinated to finally assent to being vaccinated.

At the same time information about safety problems with these vaccinations has emerged. ${ }^{1-15}$ This starts with the fact that all SARS-CoV2 vaccinations that have been approved in Germany have received what is called "red-hand letters" or security warnings by the respective authority, the Paul-Ehrlich-Institut, which is responsible for regulating vaccines. This is not surprising, as such vaccines use quite novel principles that have never been tested and approved for human usage before. These novel vaccines introduce either a viral vector or mRNA of the immunogenic part of the virus into the system of the recipient, and the cells are programmed to directly produce the antigen against which the immune system is then supposed to produce antibodies. In the case of the mRNA vaccination the spike protein of the SARS-CoV2 virus is isolated and packaged within a cationic lipid nanoparticle (LNP). Once in a cell, the mRNA is transported to ribosomes that start producing the viral spike protein which will then in turn lead to an immunological reaction. ${ }^{16-18}$ These LNPs themselves trigger a strong inflammatory reaction, which might help understand some of the side effects reported. ${ }^{19}$

Fear of side effects is one of the major drivers of vaccine hesitancy. ${ }^{20}{ }^{21}$ The vaccines are usually injected into the deltoid muscle of the patient. The substances then travel from the extracellular matrix of the muscle through the lymphatic stream to the vena cava, to the heart and lung vessels and then via the arterial system to the capillary system, where they are absorbed into the endothelial cells and tissue of each body region. The original regulatory submission document submitted by Pfizer Inc. to the Japanese regulatory agency contains evidence that, after vaccinating rats, the LNPs containing the mRNA that produce the spike protein can be found in all organs. 22, Appendix p. 6) This could explain the various side effects of the vaccines that were reported over the last year. Apart from that it is unclear, whether such a procedure might lead to „antibody dependent enhancement“. ${ }^{23} 24$ This is an immunological reaction which is due to suboptimal antigen-antibody binding, for instance if the immune system encounters a new mutant of the virus. In that case a badly bound complex of antigen and antibody cannot attach to a human immune cell, for instance a macrophage, which would then get rid of the complex, but would circulate further and induce an inflammatory cascade that is also known as a cytokine storm. This has been shown to be true for the delta-variant of the SARS-CoV2 virus. ${ }^{24}$ As these vaccines, built on the new mRNA platform technology have undergone an expedited review and have received express approval, ${ }^{2526}$ the safety tests have not been conducted, as with other vaccines, before approval, but have been conducted in parallel together with clinical testing. ${ }^{1528}$ These studies were "observer-blind" and thus had the potential of biased effects, ${ }^{29}$ especially given that the results had a marginal absolute risk reduction of $0.025 \%$ only. ${ }^{30}$ Thus, various authors reach contradictory conclusions about the safety of these substances. ${ }^{14} 15$ This insecurity is transmitted to the population via different messages transported by classical and alternative media, which are often contradictory.

Research regarding „vaccine hesitancy“ shows that roughly $60 \%$ of the population assent to being vaccinated or have already received it, ${ }^{31}$ while $20 \%-25 \%$ are against it, and the rest is undecided. ${ }^{32.36}$ Especially in Western countries - in Europe, the US and the UK - studies show that the part of the population who is in favor of these new vaccines is comparatively younger, 
economically better off, more liberal and has more trust in its government, except in the UK, where it is the part of the population that mistrusts the government that assents to being vaccinated. In summary those surveys show that not only medical, but also political reasons are being considered. This is likely due to the fact that the mainstream narrative about the Corona virus and the threat it poses has been transported by the public media and has been frontloaded with political meaning. ${ }^{37}{ }^{38} \mathrm{We}$ have seen in our own survey of German immunologists that those immunologists agreeing with the mainstream narrative were younger, were scientifically very active but more junior, and did inform themselves mainly by public channels and not by their own analyses or perusal of the scientific literature. ${ }^{39}$

We are not aware of any scientific survey data in Germany that would have looked at motivation and assent to SARS-CoV2 vaccinations. We therefore conducted such a survey. The study was designed to answer the question: Why do people consent to being vaccinated with novel vaccines against SARS-CoV2?

\section{Method}

We conducted a representative survey that was implemented by a specialized market research company, Debaro GmbH in Munich. The survey used an existing panel of approximately 30.000 respondents. The aim was to receive 1.000 complete data sets that approximate representativity of the German population. To achieve this, 3.223 respondents were invited who were preselected by demographic markers such as age, income, education and size of household to match the German population to make the sample representative according to those variables. The survey was closed when 1023 respondents had answered it, conforming to the predefined criteria. The survey was implemented online, and representativity was achieved by aligning the respondents according to the above mentioned known socioeconomic strata of the German population. The protocol of the study, including the analysis plan, was posted before commencement on the Open Science Framework platform (https://osf.io/8djbs/). The survey questions are presented in the supplementary information. There was one inadvertent protocol change: The items of group 7 in the protocol (Supp. Table 1) were originally meant to be answered by all participants, but were only presented to the unvaccinated. Therefore, they are reported in the supplement but not considered further.

\section{Statistics}

Survey data were analyzed descriptively. We were primarily interested in describing the reasons for or against vaccinations. In addition, the subgroup of vaccinated was analyzed descriptively in terms of their health status (better, equal, worse than before). There were no missing data. Motivation for or against the vaccination was then related to demographical variables and to opinions regarding SARS-CoV2. We constructed a "Corona Orthodoxy Score - COS" as developed in our survey of immunologists, where we showed its psychometric soundness and viability. ${ }^{39}$ This COS scale describes how strongly a respondent assents to the mainstream narrative about Covid19 ("The virus is more infectious, more dangerous, leads to higher mortality than flu, poses a stronger challenge to the health system than flu, and can only be overcome by vaccination which should be developed in an expedited process."). We did a second psychometric analysis of the reliability and dimensionality of the items pertaining to COS. 
We also constructed a logistic regression model for predicting vaccination status (unvaccinated $=0$; vaccinated $=1$ ) as well as readiness to be vaccinated (unvaccinated and not intending to get vaccinated $=0$; vaccinated or intending to get vaccinated $=1$ ) for an individual $i$ :

$$
\begin{aligned}
y_{i} & =\frac{\exp \left(\beta_{0}+\sum_{j=1}^{p} \beta_{j} x_{j}\right)}{1+\exp \left(\beta_{0}+\sum_{j=1}^{p} \beta_{j} x_{j}\right)}, \\
y_{i} & \in\{0,1\}, \quad i=1, \ldots, N \quad(1)
\end{aligned}
$$

Putative predictors $x_{j}$ were selected from the following 14 variables: Age, gender, income (graded, quasi-continuous), education (graded, quasi-continuous), household size (continuous), a total of eight different information sources and COS. In order to balance overfitting and model parsimony, we fitted a series of models, each with a different number of predictors $p \in$ $\{1, \ldots, 14\}$ and chose the "best" model as the one having minimum bias-corrected Akaike Information Criterion (AICc). ${ }^{40}$ For a given number of allowed predictors, we applied the least absolute shrinkage and selection operator (LASSO) method to select the best predictors from the full set of 14 predictors. ${ }^{41}$ LASSO performs variable selection by shrinking the regression coefficients of less important predictors to zero and is preferred over forward or backwards variable selection procedures. ${ }^{42}$ Prior to fitting the LASSO model, all continuous predictor variables were standardized to mean 0 and standard deviation 1 . For each number of allowed predictors, LASSO selected the ones that maximized the area under the Receiver-OperatorCharacteristic (ROC) curve of the logistic regression model, and the AICc of the model was used to compare it against all other models with a different number of predictors. The optimal model was then chosen as the one having minimal AICc, and this model was re-fit to obtain regression coefficients and their standard errors. Finally, the optimal model was used to predict an outcome for each individual in the dataset. This allowed us to estimate prediction performance (sensitivity, specificity, area under the ROC curve) on the training set.

Besides AICc, we also measured model adequacy by a Kullback-Leibler divergence-based $\mathrm{R}^{2}$ measure which was developed for generalized linear models and can be interpreted analogous to linear regression models as variance explained by the predictors. ${ }^{43}$

All analyses were calculated with $R$ version 4.0.2, and statistical significance was defined as $p$ values $<0.005$ to account for the exploratory nature of this analysis. ${ }^{44}$

\section{Results}

The study was run during the last week of November and the first week of December 2021. The final sample comprised 1032 respondents and is described in Table 1 according to vaccination status. $82 \%$ of the respondents were vaccinated $(n=855), 12.5 \%$ were unvaccinated and intended to stay so, and $4.6 \%$ were unvaccinated and intended to be vaccinated in the near future. For questions referring to unvaccinated participants these latter two groups were combined $(n=177)$. The reasons for vaccination are given in Table 2 . These could be ranked by each participant according to the first three most important reasons. Reasons for not wanting to be vaccinated are presented in Table 3 in rank order. We asked those who have been vaccinated $(n=855)$ for their health status since vaccination compared to before: $34(4.0 \%)$ reported an improved health status, 50 (5.8\%) a worse health status, while the majority $(90.2 \%)$ reported a similar health status. Furthermore, we asked the vaccinated whether they had a positive Covid19 test since being vaccinated, and about potential side effects and benefits. 
Table 1: Sociodemographic Description of the Survey Sample

\begin{tabular}{|c|c|c|c|c|c|c|}
\hline Variable & Unit & $\begin{array}{l}\text { Overall } \\
\text { cohort } \\
(n=1032)\end{array}$ & $\begin{array}{l}\text { Vaccinated } \\
(\mathrm{n}=855)\end{array}$ & $\begin{array}{l}\text { Unvaccinated, } \\
\text { not wanting } \\
\text { to become } \\
\text { vaccinated } \\
(\mathrm{n}=129)\end{array}$ & $\begin{array}{l}\text { Unvaccinated, } \\
\text { intending to } \\
\text { become } \\
\text { vaccinated } \\
(\mathrm{n}=48)\end{array}$ & p-value \\
\hline Age & $\begin{array}{l}\text { Years: Median (range) } \\
\text { Years: Mean } \pm \text { SD }\end{array}$ & $\begin{array}{l}52(16-88) \\
49.6 \pm 17.8\end{array}$ & $\begin{array}{l}54(16-88) \\
50.6 \pm 17.7\end{array}$ & $\begin{array}{l}50(16-78) \\
45.6 \pm 18.1\end{array}$ & $\begin{array}{l}39(17-74) \\
41.3 \pm 16.3\end{array}$ & $<0.0001 *$ \\
\hline Gender & $\begin{array}{l}\text { Male } \\
\text { Female } \\
\text { Diverse }\end{array}$ & $\begin{array}{c}512(49.6 \%) \\
517(50.1 \%) \\
3(0.3 \%)\end{array}$ & $\begin{array}{l}432 \\
(50.5 \%) \\
420 \\
(49.3 \%) \\
\quad 3(0.3 \%)\end{array}$ & $\begin{array}{l}57(44.2 \%) \\
72(55.8 \%) \\
0\end{array}$ & $\begin{array}{l}23(47.9 \%) \\
25(52.1 \%) \\
0\end{array}$ & 0.600 \\
\hline Education & $\begin{array}{l}\text { In training } \\
\text { No school leaving } \\
\text { certificate } \\
\text { Basic schooling } \\
\text { GCSE } \\
\text { A-level } \\
\text { University degree } \\
\text { PhD }\end{array}$ & $\begin{array}{l}11(1.1 \%) \\
6(0.6 \%) \\
223(21.6 \%) \\
375(36.6 \%) \\
188(18.2 \%) \\
213(20.6 \%) \\
16(1.6 \%)\end{array}$ & $\begin{array}{l}8(0.9 \%) \\
4(0.5 \%) \\
186 \\
(21.8 \%) \\
310 \\
(36.3 \%) \\
150 \\
(17.5 \%) \\
183 \\
(21.4 \%) \\
14(1.6 \%) \\
\end{array}$ & $\begin{array}{l}2(1.55 \%) \\
2(1.55 \%) \\
28(21.7 \%) \\
50(38.8 \%) \\
25(19.4 \%) \\
20(15.5 \%) \\
2(1.55 \%)\end{array}$ & $\begin{array}{l}1(2.1 \%) \\
0 \\
9(18.8 \%) \\
15(31.3 \%) \\
13(27.1 \%) \\
10(20.8 \%) \\
0\end{array}$ & 0.577 \\
\hline Income strata & $\begin{array}{l}<1300 € \\
1300-2000 € \\
2001-2600 € \\
2601-3600 € \\
3601-5000 € \\
>5000 €\end{array}$ & $\begin{array}{l}145(14.0 \%) \\
183(17.7 \%) \\
171(16.6 \%) \\
216(20.8 \%) \\
193(18.7 \%) \\
124(12.0 \%)\end{array}$ & $\begin{array}{l}112 \\
(13.1 \%) \\
147 \\
(17.2 \%) \\
136 \\
(20.0 \%) \\
180 \\
(21.1 \%)\end{array}$ & $\begin{array}{l}23(17.8 \%) \\
27(20.9 \%) \\
24(18.6 \%) \\
26(20.2 \%) \\
14(10.9 \%) \\
15(11.6 \%)\end{array}$ & $\begin{array}{l}10(20.8 \%) \\
9(18.8 \%) \\
11(22.9 \%) \\
10(20.8 \%) \\
4(8.3 \%) \\
4(8.3 \%)\end{array}$ & 0.084 \\
\hline
\end{tabular}


A Survey on SARS-CoV 2 Vaccination Motivation

\begin{tabular}{|c|c|c|c|c|c|c|}
\hline & & & $\begin{array}{l}175 \\
(20.5 \%) \\
105 \\
(12.3 \%)\end{array}$ & & & \\
\hline $\begin{array}{l}\text { Number of } \\
\text { persons in } \\
\text { household (as } \\
\text { categorical } \\
\text { variable) }\end{array}$ & $\begin{array}{l}1 \\
2 \\
3 \\
4 \\
5 \\
6 \\
7\end{array}$ & $\begin{array}{l}324(31.4 \%) \\
351(34.0 \%) \\
191(18.5 \%) \\
121(11.7 \%) \\
29(2.8 \%) \\
13(1.2 \%) \\
3(0.3 \%)\end{array}$ & $\begin{array}{l}268 \\
(31.3 \%) \\
311 \\
(36.4 \%) \\
154 \\
(18.0 \%) \\
89(10.4 \%) \\
22(2.6 \%) \\
9(1.1 \%) \\
2(0.2 \%)\end{array}$ & $\begin{array}{l}42(32.6 \%) \\
34(26.4 \%) \\
27(20.9 \%) \\
19(14.7 \%) \\
3(2.3 \%) \\
3(2.3 \%) \\
1(0.8 \%)\end{array}$ & $\begin{array}{l}14(29.2 \%) \\
6(12.5 \%) \\
10(20.8 \%) \\
13(27.1 \%) \\
4(8.3 \%) \\
1(2.1 \%) \\
0\end{array}$ & $0.00050 *$ \\
\hline $\begin{array}{l}\text { Number of } \\
\text { persons in } \\
\text { household (as } \\
\text { continuous } \\
\text { variable) }\end{array}$ & $\begin{array}{l}\text { Median (range) } \\
\text { Mean } \pm \text { SD }\end{array}$ & $\begin{array}{l}2(1-7) \\
2.3 \pm 1.2\end{array}$ & $\begin{array}{l}2(1-7) \\
2.2 \pm 1.2\end{array}$ & $\begin{array}{l}2(1-7) \\
2.4 \pm 1.3\end{array}$ & $\begin{array}{l}3(1-6) \\
2.8 \pm 1.4\end{array}$ & 0.013 \\
\hline
\end{tabular}

Kruskal-Wallis test and Fisher's exact test with simulated p-values were used to test for differences among the three groups in continuous and categorical variables, respectively. ${ }^{*} \mathrm{p}<0.005$ (statistically significant) 
Table 2 - Reasons for Vaccination - 3 Most Important Reasons - Frequencies (Percent) Vaccinated persons or those with intention to be vaccinated only $(n=903)$

\begin{tabular}{|l|l|l|l|}
\hline Reason & First rank & Second rank & Third rank \\
\hline $\begin{array}{l}\text { I fear the health consequences of an } \\
\text { infection with the corona virus }\end{array}$ & $542(60.0 \%)$ & $115(12.7 \%)$ & $98(10.8 \%)$ \\
\hline $\begin{array}{l}\text { I want to contribute eradicating the } \\
\text { virus }\end{array}$ & $93(10.3 \%)$ & $268(29.7 \%)$ & $233(25.8 \%)$ \\
\hline I want to be able to lead a normal life & $163(18.5 \%)$ & $266(29.5 \%)$ & $272(30.1 \%)$ \\
\hline I want to travel again & $71(7.9 \%)$ & $150(16.6 \%)$ & $143(15.8 \%)$ \\
\hline My social environment exerts pressure & $29(3.2 \%)$ & $78(8.6 \%)$ & $85(9.4 \%)$ \\
\hline I do it because others do it as well & $5(0.5 \%)$ & $26(2.9 \%)$ & $72(8.0 \%)$ \\
\hline
\end{tabular}

Table 3 - Reasons for Not Wanting to be Vaccinated - 3 Most Important reasons -

Frequencies (Percent) - Unvaccinated persons only $(\mathrm{n}=129)$

\begin{tabular}{|l|l|l|l|}
\hline Reason & First rank & Second rank & Third rank \\
\hline $\begin{array}{l}\text { I have received many terrible } \\
\text { informations }\end{array}$ & $7(5.4 \%)$ & $20(15.5 \%)$ & $47(36 \%)$ \\
\hline $\begin{array}{l}\text { I do not want to be treated with } \\
\text { vaccinations whose long term effects } \\
\text { are unknown }\end{array}$ & $52(40.3 \%)$ & $47(36.4 \%)$ & $13(10.1 \%)$ \\
\hline I am afraid of side effects & $47(36.4 \%)$ & $43(33.3 \%)$ & $18(13.9 \%)$ \\
\hline I don't think we need a vaccination & $12(9.3 \%)$ & $10(7.7 \%)$ & $30(23.2 \%)$ \\
\hline I have had Covid and am immune & $3(2.3 \%)$ & $3(2.3 \%)$ & $10(7.7 \%)$ \\
\hline I principally don't do what others do & $8(6.2 \%)$ & $6(4.6 \%)$ & $11(8.5 \%)$ \\
\hline
\end{tabular}

Table 4 - In Vaccinated only $(\mathrm{n}=855)$ : Covid 19 positive Test, Potential Side Effects and Potential Improvements (yes answers only), Beliefs

\begin{tabular}{|l|l|l|}
\hline & Yes & No\$ \\
\hline $\begin{array}{l}\text { Covid } 19+\text { test since } \\
\text { vaccination }\end{array}$ & $84(9.8 \%)$ & $771(90.2 \%)$ \\
\hline Potential side effects... & & \\
\hline Thrombosis or embolies & $12(1.4 \%)$ & \\
\hline Psychological stress & $60(7.0 \%)$ & \\
\hline $\begin{array}{l}\text { Other problems with blood } \\
\text { vessel }\end{array}$ & $22(2.6 \%)$ & \\
\hline Lack of stamina & $66(7.7 \%)$ & \\
\hline Immunological problems & $23(2.7 \%)$ & \\
\hline None of the above & $721(84.3 \%)$ & \\
\hline $\begin{array}{l}\text { Better since vaccination } \\
\text { because of... }\end{array}$ & & \\
\hline Relief & $126(14.7 \%)$ & \\
\hline More stamina & $28(3.3 \%)$ & \\
\hline $\begin{array}{l}\text { Other physical problems } \\
\text { disappeared }\end{array}$ & $20(2.3 \%)$ & \\
\hline Better social integration & $127(14.8 \%)$ & \\
\hline Better immune function & $42(4.9 \%)$ & \\
\hline None of the above & $595(69.6 \%)$ & \\
\hline
\end{tabular}




\begin{tabular}{|l|l|l|}
\hline $\begin{array}{l}\text { Vaccination protects from } \\
\text { infecting others with } \\
\text { Covid19 }\end{array}$ & $608(71.1 \%)$ & $247(28.9 \%)$ \\
\hline $\begin{array}{l}\text { Vaccination protects oneself } \\
\text { from contracting Covid19 }\end{array}$ & $301(35.2 \%)$ & $554(64.8 \%)$ \\
\hline
\end{tabular}

$\$$ frequencies of no answers are given where forced entry avoided missing data, else only yes answers provided and the rest is due to missing data, because the answer was not forced to be either yes or no

These data are presented in Table 4. We asked those who were unvaccinated for positive Covid19 tests, Covid-19 disease, health system use, and problems they might have had because of various issues. This is presented in Supplementary Table 1. Table 5 presents opinion items on SARS-CoV2 that also form the basis for the construction of our "Covid-19 Orthodoxy Score COS", and Table 6 presents data on information sources of the participants.

Table 5 - Opinions regarding SARS-CoV2 - Items of the "Covid Orthodoxy Score" (marked with asterisk; $\mathrm{n}=1032$ )

\begin{tabular}{|c|c|c|c|c|}
\hline $\begin{array}{l}\text { SARS-CoV2 } \\
\text { compared to } \\
\text { seasonal flu in } \\
\text { terms of }\end{array}$ & Less & Similar & More & Much More \\
\hline *Infectivity & $35(3.4 \%)$ & $199(19.3 \%)$ & $248(24.0 \%)$ & $550(53.3 \%)$ \\
\hline $\begin{array}{l}\text { *Infection } \\
\text { fatality rate }\end{array}$ & $67(6.5 \%)$ & $229(22.2 \%)$ & $263(25.5 \%)$ & $473(45.8 \%)$ \\
\hline $\begin{array}{l}* \text { Challenge to } \\
\text { the health } \\
\text { system }\end{array}$ & $35(3.4 \%)$ & $216(20.9 \%)$ & $293(28.4 \%)$ & $488(47.3 \%)$ \\
\hline \multirow[t]{2}{*}{$\begin{array}{l}\text { *More } \\
\text { important is }\end{array}$} & $\begin{array}{l}\text { the immune } \\
\text { system }\end{array}$ & the virus & & \\
\hline & $662(64.1 \%)$ & $370(35.8 \%)$ & & \\
\hline \multirow[t]{2}{*}{$\begin{array}{l}\text { *Vaccine } \\
\text { development }\end{array}$} & Not necessary & $\begin{array}{l}\text { Normal order } \\
\text { and sequence } \\
\text { should be kept }\end{array}$ & $\begin{array}{l}\text { Expedited } \\
\text { development } \\
\text { necessary }\end{array}$ & \\
\hline & $64(6.2 \%)$ & $518(50.2 \%)$ & $450(43.6 \%)$ & \\
\hline \multirow{2}{*}{$\begin{array}{l}\text { Most damage } \\
\text { was done by\# }\end{array}$} & *The virus & *NPIs & Media & Fake News \\
\hline & $479(46.4 \%)$ & $453(43.9 \%)$ & $298(28.9 \%)$ & $482(46.7 \%)$ \\
\hline
\end{tabular}

\# multiple answers possible

Table 6 - My information sources during the pandemic are mainly

\begin{tabular}{|l|l|}
\hline Source & Yes \\
\hline No information & $75(7.3 \%)$ \\
\hline Public TV and radio & 461 \\
& $(44.7 \%)$ \\
\hline Social Media (Twitter, Facebook, etc.) & $66(6.4 \%)$ \\
\hline Scientific original publications & $65(6.3 \%)$ \\
\hline
\end{tabular}




\begin{tabular}{|l|l|}
\hline $\begin{array}{l}\text { Alternative media (Websites, Youtube, alternative newspapers on the } \\
\text { internet) }\end{array}$ & $102(9.9 \%)$ \\
\hline Own analysis of publicly available data (e.g. RKI, CDC, ECDC, PEI, etc.) & $79(7.6 \%)$ \\
\hline $\begin{array}{l}\text { Traditional newspapers and magazines (e.g. SZ, SZ-online, Spiegel, Spiegel- } \\
\text { online) }\end{array}$ & $\begin{array}{l}117 \\
(11.3 \%)\end{array}$ \\
\hline Exchange with colleagues and friends & $55(5.3 \%)$ \\
\hline Other sources* & $12(0.1 \%)$ \\
\hline
\end{tabular}

*Mix of all of them, RKI, web.de, other news, school, mix of scientists in media and TV

We used our previously reported "Covid-19 Orthodoy Score - COS" that consists of the items asking about the opinion on SARS-CoV2 (Table 6, items with asterisk). ${ }^{39}$ We replicated its internal consistency or reliability as alpha $=0.76$ with a mean item-intercorrelation of $\mathrm{r}_{\mathrm{it}}=0.32$. The scale was unidimensional, explaining $42.8 \%$ of the variance.

We calculated two logistic regression models to predict vaccination status (model 1: unvaccinated $=0$, vaccinated $=1$ ) and readiness to be vaccinated (model 2: not willing=0; willing=1). The results are presented in Table 7 , and the predictive performance is shown in Figure 1. A total of seven variables were selected into the optimal model for predicting vaccination status (according to the minimum AICc), while only three variables were needed to optimize the model for predicting the readiness to be vaccinated. The latter model also resulted in slightly better overall prediction performance as judged by both KL- $\mathrm{R}^{2}$ and the area under the ROC curve (Figure 1b). The specificity, i.e., the ability to achieve a true positive prediction for a vaccinated person or a person intending to be vaccinated, respectively, was high for both models $(81.8 \%$ and $89.9 \%$, respectively), but sensitivity was only moderate. Overall prediction accuracy was $>75 \%$. The COS was the major predictor of vaccination outcome in both models and on its own able to explain about $17.4 \%$ and $24.2 \%$ of the variance in model 1 and 2 , respectively, according to the KL- $\mathrm{R}^{2}$ value. Higher income, being older and public TV and radio use were positively associated with vaccination status, while greater household size and the use of alternative media and scientific original publications were negatively associated with being vaccinated. The use of public TV and radio was also a positive predictor of readiness to be vaccinated, while reading original scientific publications decreased the odds of a past or a future vaccination. 
Table 7 - Optimal logistic regression models to predict vaccination outcomes

\begin{tabular}{|c|c|c|c|c|c|c|}
\hline \multirow{2}{*}{$\begin{array}{l}\text { Model } \\
\text { Predictor }\end{array}$} & \multicolumn{3}{|c|}{ 1: Vaccination status } & \multicolumn{3}{|c|}{ 2: Willingness to be vaccinated } \\
\hline & Estimate \pm SE & p-value & $\begin{array}{l}\text { OR } \\
(95 \% \mathrm{CI})\end{array}$ & $\begin{array}{l}\text { Estimate } \pm \\
\text { SE }\end{array}$ & \begin{tabular}{|l|}
$p-$ \\
value
\end{tabular} & $\begin{array}{l}\text { OR }(95 \% \\
\text { CI })\end{array}$ \\
\hline $\begin{array}{l}\text { Orthodoxy } \\
\text { Score }\end{array}$ & $0.33 \pm 0.03$ & $\begin{array}{l}<2 \times 10^{-16} \\
*\end{array}$ & $\begin{array}{l}1.39 \\
(1.30 \\
1.47)\end{array}$ & $0.41 \pm 0.04$ & $\begin{array}{l}<2 \times 10^{-} \\
16 *\end{array}$ & $\begin{array}{l}1.50(1.40- \\
1.62)\end{array}$ \\
\hline Income & $0.236 \pm 0.064$ & $0.00025 *$ & $\begin{array}{l}1,27 \\
(1.12- \\
1.44) \\
\end{array}$ & - & - & - \\
\hline $\begin{array}{l}\text { Alternative } \\
\text { Media Use }\end{array}$ & $-0.81 \pm 0.27$ & $0.0024 *$ & $\begin{array}{l}0.44 \\
(0.26- \\
0.75)\end{array}$ & - & - & - \\
\hline $\begin{array}{l}\text { Scientific } \\
\text { Original } \\
\text { Publications } \\
\text { Use }\end{array}$ & $-0.88 \pm 0.35$ & 0.011 & $\begin{array}{l}0.42 \\
(0.21- \\
0.82)\end{array}$ & $-0.60 \pm 0.37$ & 0.104 & $\begin{array}{l}0.55(0.27- \\
1.13)\end{array}$ \\
\hline $\begin{array}{l}\text { Size of } \\
\text { Household }\end{array}$ & $-0.193 \pm 0.085$ & 0.024 & $\begin{array}{l}0.82 \\
(0.70- \\
0.97)\end{array}$ & - & - & - \\
\hline $\begin{array}{l}\text { Age [10 } \\
\left.\text { years }^{-1}\right]\end{array}$ & $0.094 \pm 0.059$ & 0.114 & $\begin{array}{l}1.01(1.0- \\
1.02)\end{array}$ & - & - & - \\
\hline $\begin{array}{l}\text { Public TV } \\
\text { and Radio } \\
\text { Use }\end{array}$ & $0.15 \pm 0.23$ & 0.513 & $\begin{array}{l}1.16 \\
(0.74- \\
1.84) \\
\end{array}$ & $0.51 \pm 0.26$ & 0.046 & $\begin{array}{l}1.67(1.01- \\
2.75)\end{array}$ \\
\hline $\mathrm{AICc}$ & \multicolumn{3}{|l|}{756.4} & \multicolumn{3}{|l|}{588.7} \\
\hline Adj. KL-R ${ }^{2}$ & \multicolumn{3}{|l|}{0.212} & \multicolumn{3}{|l|}{0.251} \\
\hline Sensitivity & \multicolumn{3}{|l|}{0.684} & \multicolumn{3}{|l|}{0.669} \\
\hline Specificity & \multicolumn{3}{|l|}{0.819} & \multicolumn{3}{|l|}{0.899} \\
\hline Accuracy & \multicolumn{3}{|l|}{0.752} & \multicolumn{3}{|l|}{0.784} \\
\hline AUC & \multicolumn{3}{|l|}{0.818} & \multicolumn{3}{|l|}{0.844} \\
\hline
\end{tabular}

Intercept calculated but omitted. Sensitivity and specificity are those that maximize the overall accuracy of classification. Adj. KL-R ${ }^{2}=$ adjusted Kullback-Leibler-R ${ }^{2}$; AICc=biascorrected Akaike Information Criterion; $\mathrm{AUC}=$ area under the curve; OR $(95 \% \mathrm{CI})=\mathrm{Odds}$ Ratio (95\% Confidence Interval) 

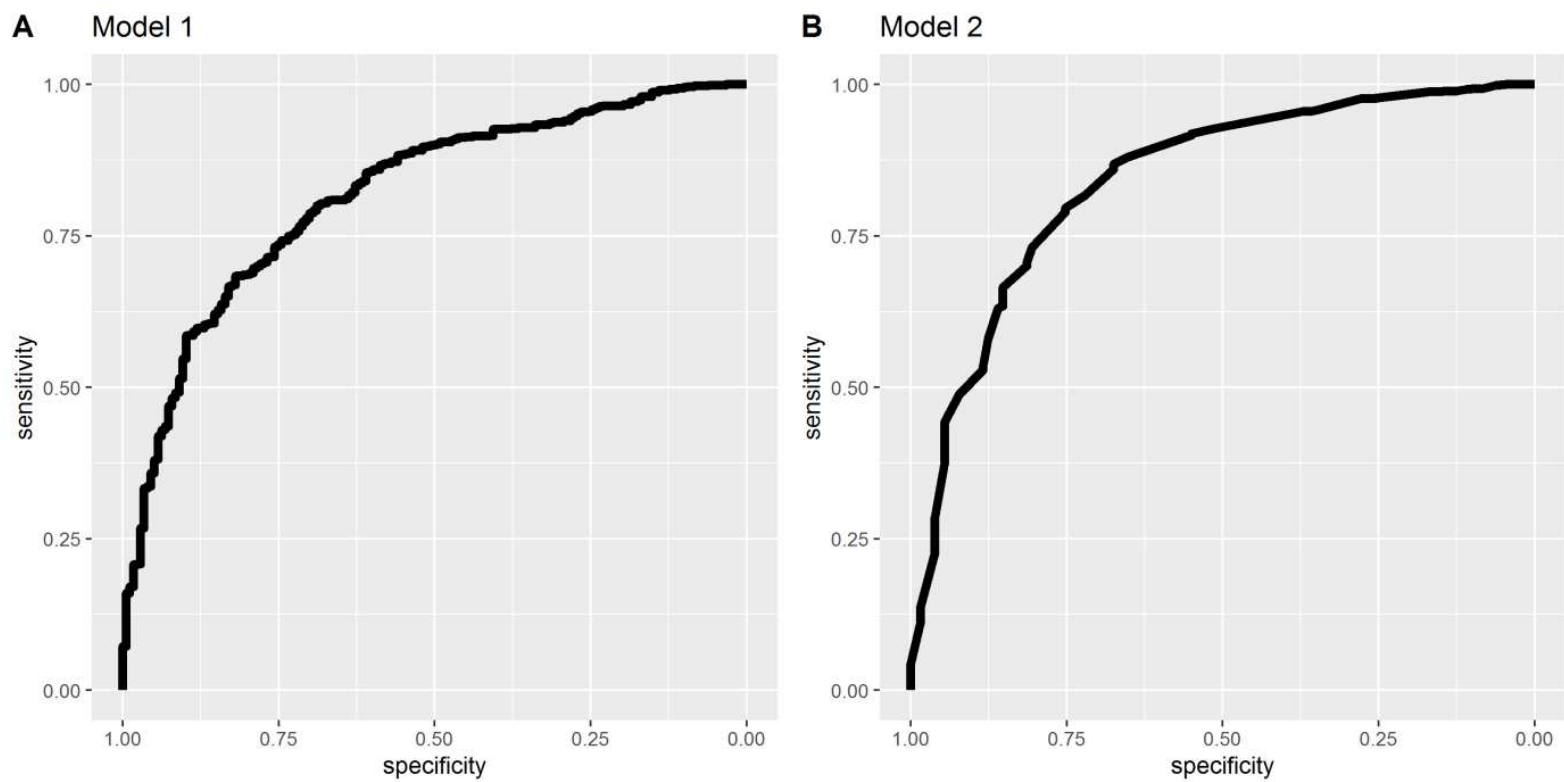

Figure 1: Receiver-Operator-Characteristics (ROC) curves for model 1 (predicting vaccination status) and 2 (predicting willingness to be vaccinated). 


\section{Discussion}

To our knowledge this is the first representative survey in Germany on the motivation to be vaccinated or not with Covid-19 vaccines. More than $80 \%$ of our respondents were vaccinated at the time of the survey, end of November and first week of December 2021. The major reason for vaccination was fear of health consequences (about 60\%). The average age of the population in this survey is 49.6 years and the infection fatality rate for this age group is between $0.01 \%$ and $0.1 \% .{ }^{45}$ This fear is likely due to media coverage and consumption, ${ }^{46}$ and we know from psycho-neuroendocrinological research that fear, stress and negative emotions impair natural immunity. ${ }^{47}$ The second most important reason was the desire to be able to lead a normal life, to be able to travel, go to restaurants, bars, concerts and other social events (about 46\%). This major driver is probably influenced by the various restrictions people had to endure because of Nonpharmacological Interventions (NPIs) imposed by political decisions. Whether such NPIs are at all effective is questionable. ${ }^{48.53} \mathrm{~A}$ third reason was to help eradicate the virus. Recent data show that the vaccines do not help break transmissions chains and thus cannot really eradicate the virus. ${ }^{5455}$

Those who were not vaccinated gave as major reason the lack of knowledge of long-term efficacy and safety. A secondary reason was the fear of side effects. This is in line with the fact that the incidence of reported side effects just within the last year of using these vaccines is at least 20 times higher than for other vaccines together over the last 20 years. For instance, the German Adverse Reaction Database of the Paul-Ehrlich-Institut reports 456 cases of deaths and 54.488 reports altogether for all vaccinations, excluding Covid-19 vaccines, since 2000

(http://52625146fm.pei.de/fmi/webd/\#UAWDB, accessed 20 th Dec 2021), while the cases of deaths reported after Covid-19 vaccines amount to 1.802 among 171.415 total reports in the most recent report of Sept $30^{\text {th }} 2021$

(https://www.pei.de/SharedDocs/Downloads/DE/newsroom/dossiers/sicherheitsberichte/sic herheitsbericht-27-12-20-bis-30-09-21.pdf? blob=publicationFile\&v $=10$, accessed $20^{\text {th }}$ Dec 2021). Thus, the reports of all vaccinations together per year are $1.6 \%$ of the number of reports due to Covid-19 vaccines over the last year.

Slightly more of those vaccinated, namely $5.8 \%$ described their health status after vaccination worse than before, while $4 \%$ said it was better, which would put the strategy to advocate these vaccines into question. Nearly $10 \%$ had a positive SARS-CoV2 test after vaccination. This tallies with recent information that a majority of new Covid-19 cases in Germany is vaccinated. ${ }^{56}$ Sixteen percent of those vaccinated described some kind of serious side effect, such as thrombosis, immunological dysfunction, psychological stress or lack of stamina. The official rate of all side effect reports according to the Paul-Ehrlich-Institut safety reports is 1.6 reports in 1'000 vaccinations. Thus, our figure is about 100 times as high, which tallies with empirical studies that show that only $1 \%$ of all side effects are reported in adverse reaction databases. ${ }^{1457-59}$ Taking into consideration that $16 \%$ of all vaccinated people in Germany would face serious side effects, this would amount to roughly 12 million cases. Roughly $30 \%$ of our respondents felt better after the vaccination. We assume this is because of psychological relief and better social integration.

The logistic regression models were able to predict vaccination status as well as readiness to be vaccinated with more than $75 \%$ accuracy (Table 7 and Figure 1). Persons living in smaller households, with higher income, with a stronger adherence to the mainstream narrative and less usage of alternative media and scientific papers were more likely to be vaccinated. Likewise, a higher readiness to be vaccinated was mainly predicted by a stronger adherence to the mainstream narrative, more usage of public and less usage of scientific information sources. 
This is similar to findings of an Australian survey, where the willingness to be vaccinated was lower in better educated participants and in infrequent users of traditional media. ${ }^{20}$ Our findings are in accord with other studies regarding willingness to be vaccinated. ${ }^{20} 60$

While income plays a role in the decision of being vaccinated, education does not. The most important predictor is the adherence to the mainstream narrative, a high "orthodoxy score" calculated from our opinion items. This scale, already developed in another study, ${ }^{39}$ was psychometrically reliable with a reasonable alpha $=0.76$ and unidimensional. This was the most powerful predictor in our logistic regression models to predict vaccination status and the readiness to be vaccinated. In addition, alternative media use also plays an important role, as does the consultation of scientific papers. Persons who were vaccinated used scientific information and alternative media less. During the pandemic it could be observed how opinions divergent from the mainstream narrative drifted into alternative media channels and were less represented by mainstream media. Hence it is understandable that those who took their information from such channels are more skeptical than others. Most notably, social media do not play a role in influencing the motivation for vaccination in the general population similar to other findings. ${ }^{20}$ Mainstream media such as TV and newspapers were not significantly associated with the outcomes, contrary to other findings, ${ }^{61}$ probably because most of this variance is absorbed by the orthodoxy score which reflects the mainstream opinion that is also propagated by mainstream media.

We note that benefits from the vaccination are reported by $30 \%$ of the respondents. These are very likely psychological and social in nature. Psychologically speaking, these are negative reinforcements: by being relieved of a punishment, such as social distancing and psychological stress.

It is understandable that people unwilling to be vaccinated cite potential long-term safety issues as the most important reason for their hesitancy. As these are probably more likely to be represented in alternative media channels this makes plausible that alternative media use is a strong predictor in our logistic regression model. This problem will not go away by increasing the propaganda noise pro vaccination, but only by careful, longitudinal and proactive efficacy and safety monitoring that is the only method to eventually prove vaccine safety.

We also note that more than $70 \%$ of the respondents think they can stop the spread of the virus by being vaccinated and 35\% believe they can protect themselves from the disease (Table 4). Both opinions were originally propagated as major reasons for vaccinations, but have turned out to be wrong. The efficacy of the Covid-19 vaccine wanes quickly ${ }^{62}$ and is gone after 6 months. ${ }^{63}$ The vaccination level is unrelated to the increase in new cases. ${ }^{64}$ Also, it is not yet known if the vaccines have any effects against new mutations.

Obviously, misleading information led to wrong perceptions of safety and illusion of control, a deeply rooted human motive. ${ }^{65}$ This might inform decisions based on wrong assumptions. In such a situation informed consent between a physician and patient, as justification for any medical intervention, might be critically compromised and poses risks for doctors, e.g. insurance exits, criminal investigations and limitations to work as a doctor. This might be even more critical in so called "vaccination centers" with very limited time to inform patients about the probable benefits and possible risks of the intervention.

A majority of our respondents, $64 \%$, similar to the $52 \%$ of all immunologists surveyed by us, find that the immune system is more important than the virus in this pandemic. Political strategies have not at all respected this potentially crucial point. Lockdowns, social isolation, 
fear, uncertainty and stress hamper immunological competency. Perhaps it would be more fruitful to spend energy on campaigns improving immune competency than on combating a virus, for instance by improving vitamin $\mathrm{D}$ levels in the population or by encouraging exercise and activity in the open air.

Our study had limitations:

Our survey was only approximately representative. It arose from a professional market survey panel of respondents that are remunerated and are used to giving their opinion. We sampled $82 \%$ of vaccinated persons at a time where the official figure of fully vaccinated persons in Germany is $69,3 \%$ (https://impfdashboard.de/ accessed $9^{\text {th }}$ Dec 2021 ) or $72,3 \%$ according to the data of the German Public Health authority Robert-Koch-Institut

(https://www.rki.de/DE/Content/InfAZ/N/Neuartiges_Coronavirus/Daten/Impfquotenmon itoring.xlsx? _blob=publicationFile accessed $9^{\text {th }}$ Dec 2021), similar to another recent survey in the UK. ${ }^{60}$ This is probably due to the fact that we did not differentiate between single and double shot vaccination, because we were interested in the willingness and reasons to be vaccinated in principle, and not in the vaccination status as such. It might also mean that our sample was not fully representative, or that public data lag behind. The representativeness of data for the German population can be approximated with about 1000 respondents, but will of course suffer at the margins. By predefining the most important structural parameters of representativeness we have reduced bias, but bias can never be fully excluded with online panels. However, our socio-economic strata and age groups show that we have approximated a representative sample of the German population.

One block of additional items (Supp. Table 1) was originally meant for all participants but was only presented to those not vaccinated due to a programming oversight.

\section{Conclusion}

The motivation to be vaccinated is mainly due to fear of medical consequences of an infection with SARS-CoV2, followed by the wish to have a normal life. The motivation to stay unvaccinated is driven by worries regarding long term safety aspects of the vaccines and fear of side effects. Persons who have been vaccinated are more likely to be economically better off, to live in smaller households, follow the mainstream narrative about SARS-CoV2 and less likely to use alternative media or original scientific papers as information sources. If the vaccine hesitancy is to be overcome long-term, active safety and efficacy monitoring systems have to be installed. 


\section{Literature}

1. Rose J. A report on the U.S. vaccine adverse events reporting system (VAERS) on the Covid19 messenger ribonucleic acid (mRNA) biologicals. Science, Public Health Policy, and the Law 2021;2:59-80.

2. Seneff S, Nigh G. Worse than the disease? Reviewing some possible unintended consequences of the mRNA vaccines against COVID-19. International Journal of Vaccine Theory, Practice, and Research 2021;2(1):38-79.

3. Kowarz E, Krutzke L, Reis J, et al. "Vaccine-Induced Covid-19 Mimicry" Syndrome: Splice reactions within the SARS-CoV-2 Spike open reading frame result in Spike protein variants that may cause thromboembolic events in patients immunized with vectorbased vaccines. Research Square 2021 doi: 10.21203/rs.3.rs-558954/v1

4. Krutzke L, Roesler R, Wiese S, et al. Process-related impurities in the ChAdOx1 nCov-19 vaccine. Nature Portfolio 2021 doi: 10.21203/rs.3.rs-477964/v1

5. Sahelian R. Covid Vaccine Side Effects 2021 [Available from: https://www.raysahelian.com/covidvaccinesideeffects.html.

6. Shimabukuro TT, Kim SY, Myers TR, et al. Preliminary Findings of mRNA Covid-19 Vaccine Safety in Pregnant Persons. New England Journal of Medicine 2021;384(24):227382. doi: 10.1056/NEJMoa2104983

7. Gerber GF, Yuan X, Yu J, et al. COVID-19 vaccines induce severe hemolysis in paroxysmal nocturnal hemoglobinuria. Blood 2021;137(26):3670-73. doi: 10.1182/blood.2021011548

8. Hippisley-Cox J, Patone M, Mei XW, et al. Risk of thrombocytopenia and thromboembolism after covid-19 vaccination and SARS-CoV-2 positive testing: self-controlled case series study. BMJ 2021;374:n1931. doi: 10.1136/bmj.n1931

9. Lehmann KJ. Suspected cardiovascular side effects of two Covid-19 vaccines. Journal of Biology and Today's World 2021;10(5):1-6.

10. Lyons-Weiler J. If Vaccine Adverse Events Tracking Systems Do Not Support Causal Inference, then "Pharmacovigilance" Does Not Exist. Science, Public Health Policy, and the Law 2021;3:81-86. doi: https://cf5e727d-d02d-4d71-89ff9fe2d3ad957f.filesusr.com/ugd/adf864 4588b37931024c5d98e35a84acf8069a.pdf

11. Lyons-Weiler J. Pathogenic priming likely contributes to serious and critical illness and mortality in COVID-19 via autoimmunity. Journal of Translational Autoimmunity 2020;3:100051. doi: https://doi.org/10.1016/j.jtauto.2020.100051

12. Walach H, Klement RJ, Aukema W. The Safety of COVID-19 Vaccinations - Should We Rethink the Policy? Science, Public Health Policy, and the Law 2021;3:87-99. doi:

https://www.publichealthpolicyjournal.com/general-5

13. Li C, Chen Y, Zhao Y, et al. Intravenous Injection of Coronavirus Disease 2019 (COVID19) mRNA Vaccine Can Induce Acute Myopericarditis in Mouse Model. Clinical Infectious Diseases 2021 doi: 10.1093/cid/ciab707

14. Kostoff RN, Calina D, Kanduc D, et al. Why are we vaccinating children against COVID19? . Toxicology Reports 2021;8:1665-84. doi: 10.1016/j.toxrep.2021.08.010

15. Thomas SJ, Moreira ED, Kitchin N, et al. Safety and Efficacy of the BNT162b2 mRNA Covid-19 Vaccine through 6 Months. New England Journal of Medicine 2021;385(19):1761-73. doi: 10.1056/NEJMoa2110345 
16. Pilkington EH, Suys EJA, Trevaskis NL, et al. From influenza to COVID-19: Lipid nanoparticle mRNA vaccines at the frontiers of infectious diseases. Acta Biomaterialia 2021;in print doi: https://doi.org/10.1016/j.actbio.2021.06.023

17. Schoenmaker L, Witzigmann D, Kulkarni JA, et al. mRNA-lipid nanoparticle COVID-19 vaccines: Structure and stability. International Journal of Pharmaceutics 2021;601:120586. doi: https://doi.org/10.1016/j.ijpharm.2021.120586

18. Ivanova E, Devlin J, Buus T, et al. Discrete Immune Response Signature to SARS-CoV-2 mRNA Vaccination Versus Infection. . SSRN Preprint 2021 doi: http://dx.doi.org/10.2139/ssrn.3838993

19. Ndeupen S, Qin Z, Jacobsen S, et al. The mRNA-LNP platform's lipid nanoparticle component used in preclinical vaccine studies is highly inflammatory. bioRxiv 2021 doi: 10.1101/2021.03.04.430128 [published Online First: 2021/03/11]

20. Alley SJ, Stanton R, Browne M, et al. As the Pandemic Progresses, How Does Willingness to Vaccinate against COVID-19 Evolve? International Journal of Environmental Research and Public Health 2021;18(2):797.

21. Peretti-Watel P, Seror V, Cortaredona S, et al. A future vaccination campaign against COVID-19 at risk of vaccine hesitancy and politicisation. The Lancet Infectious Diseases 2020;20(7):769-70. doi: 10.1016/S1473-3099(20)30426-6

22. Pfizer Inc. mRNA vaccine against Covid-19 - Submission for regulatory approval in Japan. Tokyo: Pharmaceutical and Medical Devices Agency, 2020.

23. Iwasaki A, Yang Y. The potential danger of suboptimal antibody responses in COVID-19. Nature Reviews Immunology 2020;20(6):339-41. doi: 10.1038/s41577-020-0321-6

24. Yahi N, Chahinian H, Fantini J. Infection-enhancing anti-SARS-CoV-2 antibodies recognize both the original Wuhan/D614G strain and Delta variants. A potential risk for mass vaccination? Journal of Infection 2021 doi: 10.1016/j.jinf.2021.08.010

25. Doshi P. Covid-19 vaccines: In the rush for regulatory approval, do we need more data? BMJ 2021;373:n1244. doi: 10.1136/bmj.n1244

26. Food and Drug Administration. Fact Sheet for Healthcare Providers Administering Vaccine: Emergency use authorization (eua) of the pfizer-biontech covid-19 vaccine to prevent coronavirus disease 2019 (covid-19). Washington: Food and Drug Administration, 2021.

27. Baden LR, El Sahly HM, Essink B, et al. Efficacy and Safety of the mRNA-1273 SARS-CoV2 Vaccine. New England Journal of Medicine 2020;384(5):403-16. doi: 10.1056/NEJMoa2035389

28. Polack FP, Thomas SJ, Kitchin N, et al. Safety and Efficacy of the BNT162b2 mRNA Covid-19 Vaccine. New England Journal of Medicine 2020;383(27):2603-15. doi: 10.1056/NEJMoa2034577

29. Tanveer S, Rowhani-Farid A, Hong K, et al. Transparency of COVID-19 vaccine trials: decisions without data. BMJ Evidence-Based Medicine 2021:bmjebm-2021-111735. doi: 10.1136/bmjebm-2021-111735

30. Olliaro P, Torreele E, Vaillant M. COVID-19 vaccine efficacy and effectiveness - the elephant (not) in the room. The Lancet Microbe 2021;2(7):e279-e80. doi: 10.1016/S26665247(21)00069-0

31. MacDonald NE. Vaccine hesitancy: Definition, scope and determinants. Vaccine 2015;33(34):4161-64. doi: https://doi.org/10.1016/j.vaccine.2015.04.036

32. Fathalla Aboelsaad IA, Hafez DM, Almaghraby A, et al. Systematic Review and Metaanalysis on COVID-19 Vaccine Hesitancy. medRxiv 2021:2021.05.15.21257261. doi: 10.1101/2021.05.15.21257261 
33. Savoia E, Su M, Piltch-Loeb R, et al. Understanding COVID-19 Vaccine Early Skepticism and Misinformation. medRxiv 2021:2021.07.21.21260881. doi: 10.1101/2021.07.21.21260881

34. Kerdoun MA, Henni AH, Yamoun A, et al. COVID-19 vaccine hesitancy among Algerian medical students: a cross-sectional study in five universities. medRxiv 2021:2021.08.29.21261803. doi: 10.1101/2021.08.29.21261803

35. Roberts Ch, Brindle H, Rogers NT, et al. Vaccine Confidence and Hesitancy at the start of COVID-19 vaccine deployment in the UK: An embedded mixed-methods study. medRxiv 2021:2021.07.13.21260425. doi: 10.1101/2021.07.13.21260425

36. Piltch-Loeb R, Silver D, Kim Y, et al. Determinants of the COVID-19 Vaccine Hesitancy Spectrum. medRxiv 2021:2021.08.05.21261675. doi: 10.1101/2021.08.05.21261675

37. Meyen M. Die Propaganda Matrix: Der Kampf für freie Medien entscheided über unsere Zukunft [The Propaganda Matrix: The Fight for Free Media Decides our Future]. München: Rubikon 2021.

38. Walach H. Das Ei und Corona. Jahrbuch Psychotherapie 2021;1:31-42.

39. Walach H, Ruof V, Hellweg R. German Immunologists' Opinion on SARS-CoV2 - Results of an Online Survey. Cureus 2021:e19393. doi: 10.7759/cureus

40. Anderson DR. Model Based Inference in the Life Sciences: A primer on Evidence. New York: Springer Science+Business Media LLC 2008.

41. Tibshirani R. Regression Shrinkage and Selection via the Lasso. Journal of the Royal Statistical Society B 1996;58:267-88.

42. Harrell FEJ. Regression Modeling Strategies. 2nd ed. New York:: Springer 2015.

43. Cameron CA, Windmeijer FAG. An R-squared measure of goodness of fit for some common nonlinear regression models. Journal of Econometrics 1997;77(2):329-42. doi: https://doi.org/10.1016/S0304-4076(96)01818-0

44. Benjamin DJ, Berger JO, Johannesson $M$, et al. Redefine statistical significance. Nature Human Behaviour 2018;2(1):6-10. doi: 10.1038/s41562-017-0189-z

45. O'Driscoll M, Ribeiro Dos Santos G, Wang L, et al. Age-specific mortality and immunity patterns of SARS-CoV-2. Nature 2021;590(7844):140-45. doi: 10.1038/s41586-0202918-0

46. Bendau A, Petzold MB, Pyrkosch L, et al. Associations between COVID-19 related media consumption and symptoms of anxiety, depression and COVID-19 related fear in the general population in Germany. European Archives of Psychiatry and Clinical Neuroscience 2021;271(2):283-91. doi: 10.1007/s00406-020-01171-6

47. Kiecolt-Glaser JK, McGuire L, Robles TF, et al. Emotions, morbidity, and mortality: New perspectives from psychoneuroimmunology. Annual Review of Psychology 2002;53:83-107.

48. Kuhbandner C, Homburg S, Walach H, et al. Was Germany's Lockdown in Spring 2020 Necessary? How bad data quality can turn a simulation into a dissimulation that shapes the future. Futures 2022;135:102879. doi: https://doi.org/10.1016/j.futures.2021.102879

49. Bendavid E, Oh C, Bhattacharya J, et al. Assessing Mandatory Stay-at-Home and Business Closure Effects on the Spread of COVID-19. European Journal of Clinical Investigation 2021:e13484. doi: https://doi.org/10.1111/eci.13484

50. Chin V, Ioannidis JPA, Tanner MA, et al. Effect Estimates of COVID-19 NonPharmaceutical Interventions are Non-Robust and Highly Model-Dependent. Journal of Clinical Epidemiology 2021 doi: 10.1016/j.jclinepi.2021.03.014 
51. Sagripanti J-L, Aquilano DR. Progression of COVID-19 under the highly restrictive measures imposed in Argentina. Journal of Public Health Research 2021 doi: 10.4081/jphr.2021.2490

52. De Larochelambert Q, Marc A, Antero J, et al. Covid-19 Mortality: A Matter of Vulnerability Among Nations Facing Limited Margins of Adaptation. Frontiers in Public Health 2020;8(782) doi: 10.3389/fpubh.2020.604339

53. Chaudhry R, Dranitsaris G, Mubashir T, et al. A country level analysis measuring the impact of government actions, country preparedness and socioeconomic factors on COVID-19 mortality and related health outcomes. EClinicalMedicine 2020;25:100464. doi: https://doi.org/10.1016/i.eclinm.2020.100464

54. Singanayagam A, Hakki S, Dunning J, et al. Community transmission and viral load kinetics of the SARS-CoV-2 delta (B.1.617.2) variant in vaccinated and unvaccinated individuals in the UK: a prospective, longitudinal, cohort study. The Lancet Infectious Diseases 2021 doi: 10.1016/S1473-3099(21)00648-4

55. Bleier BS, Ramanathan M, Lane AP. COVID-19 Vaccines May Not Prevent Nasal SARSCoV-2 Infection and Asymptomatic Transmission. Otolaryngology-Head and Neck Surgery 2021;164(2):305-07. doi: 10.1177/0194599820982633

56. Kampf G. The epidemiological relevance of the COVID-19-vaccinated population is increasing. The Lancet Regional Health - Europe 2021;11:100272. doi: https://doi.org/10.1016/j.lanepe.2021.100272

57. Madigan D, Sigelman DW, Mayer JW, et al. Under-reporting of cardiovascular events in the rofecoxib Alzheimer disease studies. American Heart Journal 2012;164:186-93. doi: 10.1016/j.ahj.2012.05.002

58. Moore TJ, Bennett CL. Underreporting of Hemorrhagic and Thrombotic Complications of Pharmaceuticals to the U.S. Food and Drug Administration: Empirical Findings for Warfarin, Clopidogrel, Ticlopidine, and Thalidomide from the Southern Network on Adverse Reactions (SONAR). Semin Thromb Hemost 2012;38(08):905-07. [published Online First: 21.10.2012]

59. Golder S, Loke YK, Bland M. Meta-analyses of adverse effects data derived from randomised controlled trials as compared to observational studies: methodological overview. PLoS Medicine 2011;8(5):e1001029. doi: doi:10.1371/journal.pmed.1001026

60. Sherman SM, Sim J, Cutts M, et al. COVID-19 vaccination acceptability in the UK at the start of the vaccination programme: a nationally representative cross-sectional survey (CoVAccS - wave 2). Public Health 2022;202:1-9. doi: https://doi.org/10.1016/i.puhe.2021.10.008

61. Mercadante AR, Law AV. Will they, or Won't they? Examining patients' vaccine intention for flu and COVID-19 using the Health Belief Model. Research in Social and Administrative Pharmacy 2021;17(9):1596-605. doi: https://doi.org/10.1016/j.sapharm.2020.12.012

62. Goldberg Y, Mandel M, Bar-On YM, et al. Waning Immunity after the BNT162b2 Vaccine in Israel. New England Journal of Medicine 2021;385(24):e85. doi: 10.1056/NEJMoa2114228

63. Nordström P, Ballin M, Nordström A. Effectiveness of Covid-19 Vaccination Against Risk of Symptomatic Infection, Hospitalization, and Death Up to 9 Months: A Swedish Total-Population Cohort Study. SSRN 2021 doi: 10.2139/ssrn.3949410

64. Subramanian SV, Kumar A. Increases in COVID-19 are unrelated to levels of vaccination across 68 countries and 2947 counties in the United States. European Journal of Epidemiology 2021 doi: 10.1007/s10654-021-00808-7 
A Survey on SARS-CoV 2 Vaccination Motivation

65. Yarritu I, Matute H, Vadillo MA. Illusion of Control. Experimental Psychology 2014;61(1):3847. doi: $10.1027 / 1618-3169 / \mathrm{a} 000225$ 


\section{Acknowledgement}

We thank Tobias Aschenbrenner for implementing the survey.

\section{Funding}

The costs for data collection were sponsored by the Fairness Circle Association, a public charity.

\section{Conflict of Interest}

Markus Herbig is the CEO of the company that conducted the survey. The other authors have no conflict of interest.

\section{Author Statements}

HW designed the study, carried out part of the analysis and wrote the first draft VR did background research and helped with designing the questionnaire.

MO initiated the study, helped design the questionnaire, procured funding and wrote parts of the manuscript

$\mathrm{MH}$ collected the data.

RJK conducted the statistical analysis and wrote parts of the manuscript

All authors participated in writing, editing and finalizing the paper.

\section{Ethics Statement}

This study received ethical approval by the ethics board of the University Witten/Herdecke (S-264/2021). 


\section{Supplementary Information}

\section{Survey Questions}

1. Have you been vaccinated against SARS-CoV 2 (the „Corona-virus") or do you intend to get the shot in the near future?

(yes, no)

2. If yes: What were the reasons? Please name the three most important ones in descending order, by denoting the most important reason with 1 down to 3 :

a) I am afraid that an infection with the Corona-virus will create severe health problems, and I want to avoid these

b) I want to travel again

c) I simply want to have a normal life again, going to restaurants, cinemas, concerts, etc.

d) My social environment urges me (family, friends, workplace, learning or other social environment)

e) I want to help eradicate the virus

f) I do that because others do it also

3. If no: Why do you not want to be vaccinated? Please name the three most important reasons in descending order, by denoting the most important reason with 1 down to 3:

a) I am afraid of side effects.

b) I don't want to be treated with novel pharmaceutical products whose long-term safety profile is unclear

c) I have heard so many scary stories

d) I think a vaccination is not necessary

e) I have already had Covid19 and I am immune against it

f) I generally don't do what others do

\section{For those vaccinated:}

4. How is your state of health since having received the vaccination
a) better
b) equal
c) worse than before?

5 .

a) Did you have a positive SARS-CoV2-test since the vaccination (lateral flow or PCR test)?

b) Did you have a health problem since the vaccination (multiple answers possible)

aa) because of thromboses or embolies

bb) because of mental stress

cc) because of problems with your vessels and blood system

dd) because of reduced physical stamina

ee) because of immunological issues (allergies, auto-immune reactions, frequent infections)

c) Do you feel better since the vaccination (multiple answers possible)

aa) because of mental relief 
bb) because of better physical stamina

cc) because other physical problems disappeared since the vaccination

dd) because you have been better integrated into social life

ee) because of a better immune system

d) Do you think you are protected against Covid19 by the vaccination (yes/no)?

e) Do you think that by being vaccinated you are safe from passing on the disease to others? (yes/no)

6. For those unvaccinated and vaccinated persons before the vaccination:

a) Did you ever have a positive SARS-CoV2 test (PCR or lateral flow)?

b) Did you have a symptomatic Covid-19 disease?

aa) Did you have prolonged problems ( „long-Covid“)?

If so: How long (in weeks)

bb) Did the symptoms subside on their own?

cc) Did you have to go to hospital?

dd) Did you need intensive care?

c) Were you sad and down?

d) Were you afraid, for instance of the disease or the conseqeunces of the pandemic?

e) Did non-pharmaceutical interventions stress you (lockdown, homeoffice, face masks, distance rules, closure of businesses and shops, etc.)?

If yes, especially what (multiple answers possible):

Lockdown (closure of shops, businesses, offices, restaurants, theatres and cinemas, etc.)

Homeoffice

Social distancing

Prohibition to visit

Compulsory wearing of face masks

\section{For everyone:}

7. How severe do you think SARS-CoV2/Covid-19 is, compared to seasonal flu in terms of...?

SARS-CoV2 is...

- Much more infectious

- Somewhat more infectious

- Similarly infectious

- Less infectious

than flu.

Covid19 leads to

- Much higher mortality

- Slightly higher mortality

- Similar mortality

- less mortality

than flu 
Covid19 is putting strains on the health system

- much more

- slightly more

- similar

- less

than flu

Altogether, with SARS-CoV2 infections...

- The virus is more important than the immune system

- The immune system is more important than the virus

In developing vaccines against SARS-CoV2

- It was good to set aside the normal sequence of development (first animal and toxicity studies, then pre-clinical, then clinical and finally pivotal studies) in favor of rapid development

- The normal sequence should have been stuck to

- We don't need vaccines against this virus

Altogether more damage was done by (multiple answers)

- The virus

- The non-pharmaceutical interventions of governments (lockdown, closure of business, homeoffice, social distancing, etc..)

- Media coverage

- False information and conspiracy theories

My information about the pandemic comes mainly from

- Public TV and radio

- Conventional newspapers and their online presence

- Alternative TV and online-media (web sites, youtube, alternative and new web media)

- Scientific publications

- Social Media (Twitter, Facebook, etc.)

- Exchange with friends and colleagues

- Own analysis of publicly available data (e.g. RKI, PEI, CDC, ECDC, etc.)

- Others:....

- I do not inform myself

Sociodemographics:

Age

Gender

Schooling

General, GCSE, A-Level, University, PhD

Income strata (monthly net income in Euro)

- benefits (Hartz IV, ALG 2)

- $1.000-1.900$

- $2.000-2.900$

- $3.000-3.900$ 
A Survey on SARS-CoV 2 Vaccination Motivation

- $4.000-4.900$

- More 
Supplementary Data

Supplementary Table 1 - Unvaccinated only $(n=177)$ - Covid-19 positive test, disease, health system use

\begin{tabular}{|c|c|c|}
\hline & Yes & No\$ \\
\hline $\begin{array}{l}\text { Did you ever have a SARS- } \\
\text { CoV2 positive test }\end{array}$ & $38(21,5 \%)$ & $139(78,5 \%)$ \\
\hline $\begin{array}{l}\text { Symptomatic Covid19 } \\
\text { disease }\end{array}$ & $30(17,0 \%)$ & $147(83,0 \%)$ \\
\hline "Long Covid" & $9(5,1 \%)$ & \\
\hline $\begin{array}{l}\text { How long did "Long Covid" } \\
\text { last? (average days/median } \\
\text { [range]) }\end{array}$ & $5 / 2(2-12)$ & \\
\hline $\begin{array}{l}\text { Did symptoms abate by } \\
\text { themselves }\end{array}$ & $23(13,0 \%)$ & \\
\hline $\begin{array}{l}\text { Did you have to go to } \\
\text { hospital }\end{array}$ & $4(2,2 \%)$ & \\
\hline $\begin{array}{l}\text { Did you have to be in } \\
\text { intensive care }\end{array}$ & $1(0,6 \%)$ & \\
\hline Were you depressed? & $56(31,6 \%)$ & $121(68,4 \%)$ \\
\hline $\begin{array}{l}\text { Were you afraid of the } \\
\text { disease or its consequences }\end{array}$ & $70(39,5 \%)$ & $107(60,5 \%)$ \\
\hline $\begin{array}{l}\text { Did you have problems } \\
\text { because of NPIs }\end{array}$ & $99(55,9 \%)$ & $78(44,1 \%)$ \\
\hline \multicolumn{3}{|l|}{ Which NPIs: } \\
\hline $\begin{array}{l}\text { Lockdown, shop closure, } \\
\text { closure of companies, } \\
\text { curfews }\end{array}$ & $52(29,4 \%)$ & \\
\hline Homeoffice & $22(12,4 \%)$ & \\
\hline Social Distancing & $30(16,9 \%)$ & \\
\hline Prohibitions to visit & $62(35,0 \%)$ & \\
\hline Face masks & $60(33,9 \%)$ & \\
\hline
\end{tabular}

$\$$ direct no answers are given where forced entry avoided missing data, else only yes answers provided 